\title{
Pengaruh Lama Penyimpanan Telur terhadap Transovarial Infection Rate Virus DEN-3 pada Nyamuk Aedes aegypti
}

\section{The Effect of Egg Storage Duration on Transovarial Infection Rate of DEN-3 Virus in Aedes aegypti}

\author{
Tri Wahono ${ }^{1 *}$, Sitti Rahmah Umniyati ${ }^{2}$, Tri Baskoro Tunggul Satoto ${ }^{2}$ \\ ${ }^{1}$ Loka Litbangkes Pangandaran \\ Jalan Raya Pangandaran km 3, Pangandaran, Jawa Barat, Indonesia \\ ${ }^{2}$ Bagian Parasitologi, Fakultas Kedokteran, Universitas Gadjah Mada \\ Jalan Farmako Sekip Utara, Yogyakarta, Indonesia \\ *E_mail: triwahono1983@gmail.com
}

Received date: 30-07-2019, Revised date: 10-10-2019, Accepted date: 11-10-2019

\begin{abstract}
ABSTRAK
Transmisi transovarial virus dengue merupakan fenomena penting yang menjadi penyebab bertahannya virus dengue selama periode inter-epidemic di alam. Tujuan penelitian adalah menganalisis pengaruh lama penyimpanan telur terhadap Transovarial Infection Rate (TIR) virus DEN-3 pada nyamuk Aedes aegypti. Jenis penelitian laboratoris dengan rancangan penelitian eksperimental. Nyamuk Ae. aegypti diinfeksi virus DEN-3 secara per-oral dan dibiarkan untuk menjalani siklus gonotrofiknya. Telur kemudian disimpan pada suhu kamar $\left(25 \pm 3^{\circ} \mathrm{C}\right)$ dan kelembapan relatif $70 \pm 5 \%$ dengan variabel $0,1,2$ dan 3 bulan. Telur ditetaskan kemudian dilakukan rearing sampai menjadi nyamuk dewasa. Sampel nyamuk dewasa betina diambil dari koloni dengan variabel 4, 8, 16 hari. Sampel dibuat preparat head squash dengan metode imunositokimia Streptavidin Biotin Peroxidase Complex (SBPC) menggunakan antibodi monoklonal DSSE 10 dan dilakukan deteksi keberadaan antigen virus. Transovarial infection rate diperoleh dengan menghitung prosentase jumlah sampel positif. Data dianalisis dengan uji regresi linear. Hasil TIR pada sampel 4, 8, 16 hari diperoleh nilai terendah pada penyimpanan 0 bulan $(33,33 \% ; 33,33 \% ; 40,00 \%)$ dan tertinggi pada penyimpanan 2 bulan $(76,67 \%$; 66,67\%; $76,67 \%)$. Uji menunjukkan hasil yang berbeda nyata $(\mathrm{p}=0,013)$ dengan nilai $\alpha=0,05$ dan nilai $\mathrm{R} 2=0,476$. Lama penyimpanan telur berpengaruh terhadap TIR virus DEN-3 dengan kontribusi sebesar 47,6\%.
\end{abstract}

Kata kunci: transovarial infection rate, lama penyimpanan telur, infeksi per-oral, virus DEN-3, Aedes aegypti

\begin{abstract}
Transovarial transmission of dengue virus is important phenomenon causes dengue virus survival during interepidemic period. The purpose of this study was to analyze effect of egg storage duration on DEN-3 virus Transovarial Infection Rate (TIR) in Aedes aegypti mosquitoes. This was laboratory research with experimental design. Ae. aegypti was infected with the DEN-3 virus per-orally and allowed to undergo its gonotrophic cycle. Eggs stored at room temperature $\left(25 \pm 3^{\circ} \mathrm{C}\right)$ and relative humidity $(70 \pm 5 \%)$ for 0, 1,2 and 3 months. Hatched eggs then colonized until become adult mosquito. Sample was taken from colonies at 4, 8, 16 days old. Headsquash of mosquitoes was preparedwith Streptavidin Biotin Peroxidase Complex (SBPC) immunocytochemical method using DSSE 10 monoclonal antibody and detected the presence virus antigen. Transovarial infection rate was determined by counting percentage of positive samples. Data were analyzed by linear regression test. Result of this study showed that in 4, 8, 16 samples showed lowest TIR on 0 month storage (33,33\%, 33,33\%; 40,00\%) and highest TIR observed on 2 month storage (76,67\%; 66,67\%, 76,67\%). Statistical test showed significantly different result $(p=0,013)$ with $\alpha=0,05$ and $R 2=0,476$. The duration of egg storage effect on DEN-3 virus TIR in Ae. aegypti mosquito with $47.6 \%$ contribution.
\end{abstract}

Keywords: transovarial infection rate, egg storage duration, per-oral infection, DEN-3 virus, Aedes aegypti

\section{PENDAHULUAN}

Sejak pertama kali ditemukan di Kota Surabaya tahun 1968, angka kejadian
Demam Berdarah Dengue (DBD) memiliki kecenderungan semakin meningkat dari tahun ke tahun. Persebaran virus dengue yang 
awalnya hanya dua provinsi di tahun 1968, di tahun 2015 sudah terdistribusi di seluruh provinsi (34 provinsi) Indonesia. ${ }^{1}$ Penyakit DBD adalah penyakit yang disebabkan oleh virus dengue yang tergolong Arthropod-Borne Virus, genus Flavivirus, dan famili Flaviviridae. Berdasarkan sifat antigenisitasnya virus terdiri dari 4 serotipe yaitu DEN-1, DEN-2, DEN-3, DEN-4., Nyamuk Aedes aegypti dikenal sebagai vektor utama dan Ae. albopictus sebagai vektor sekunder. ${ }^{4}$ Kedua jenis nyamuk ini hampir terdapat di seluruh wilayah Indonesia.

Virus dengue mempertahankan keberadaanya di alam melalui dua mekanisme yaitu transmisi horizontal dan transmisi vertikal (transovarial). ${ }^{5,6}$ Transmisi transovarial adalah fenomena berpindahnya arbovirus dari jantan dan betina yang terinfeksi kepada keturunannya melalui ovarium saat oviposisi. $^{7}$

Dinamika populasi nyamuk tersebut dipengaruhi oleh faktor biotik (predator, parasit dan makanan) dan abiotik (geografi, suhu, curah hujan). Faktor lingkungan yang paling kritis terhadap pra dewasa adalah ketersediaan air dan suhu. ${ }^{8,9}$

Dalam keadaan habitat hidupnya kering semua pra dewasa akan mati, kecuali telur masih dapat bertahan hidup. Telur $A e$. aegypti mampu bertahan terhadap kekeringan selama 5 bulan pada suhu ruang dengan presentase tetas telur yang menurun setiap bulannya. $^{10}$

Umniyati menyatakan bahwa telurtelur yang diletakkan pada akhir musim hujan sebelumnya akan menetas pada awal musim hujan berikutnya, jika telur tersebut berasal dari induk infeksius, maka sebagian telur tersebut berpeluang untuk terinfeksi secara transovarial selama stadium telur yang berlangsung selama berbulan-bulan. ${ }^{11,12}$ Telur yang menetas pada musim hujan berikutnya tersebut berpeluang besar menjadi larva yang infeksius dan selanjutnya menjadi nyamuk yang infeksius virus dengue walaupun belum pernah menggigit dan menghisap darah inang infeksius virus dengue. ${ }^{11}$
Mourya et al. menyatakan bahwa telur yang diperoleh dari betina infektif virus dengue hasil inokulasi intrathoracal setelah ditetaskan paska masa inkubasi dua bulan pada suhu kamar menunjukkan peningkatan prosentase transmisi transovarial. ${ }^{6}$ Wasinpiyamongkol juga melaporkan adanya transmisi transovarial pada nyamuk F2 hasil rearing nyamuk koleksi alam yang positif dengue dari telur yang disimpan selama 1 bulan. ${ }^{13}$

Transmisi transovarial virus dengue merupakan fenomena yang penting yang menjadi penyebab bertahannya virus dengue selama periode inter-epidemic di alam. ${ }^{14}$ Transmisi transovarial virus dengue juga berperan dalam meningkatkan dan mempertahankan epidemik dengue. Tidak seperti negara-negara kontinental, dimana terjadi pergantian serotipe dengue pada negara kepulauan seperti Indonesia transmisi transovarial cenderung memainkan peran utama dalam pemeliharaan keberadaan virus dengue di suatu wilayah. ${ }^{12,15}$ Selain mempertahankan virus dengue di alam, transmisi transovarial juga berperan dalam penyebaran kasus dengue. ${ }^{16,17}$ Berdasarkan pemodelan transmisi dengue yang menggabungkan antara transmisi horizontal dan transovarial diperoleh hasil bahwa meskipun transmisi horizontal berperan penting terhadap penyebaran kasus dengue tapi saat transmisi horizontal rendah, transmisi transovarial yang berperan dalam peningkatan infeksi dengue. $^{18}$

Metode diagnosis virus dengue telah berkembang diantaranya adalah teknik imunositokimia Streptavidin Biotin Peroxidase Complex (SBPC). Teknik imunositokimia dapat mendeteksi antigen dalam jaringan secara mikroskopis dengan mikroskop cahaya. Teknik imunositokimia SBPC telah terbukti memberikan reaksi spesifik, peka, sahih, dan terandalkan untuk mendeteksi virus dengue pada nyamuk Ae. aegypti di bawah mikroskop cahaya. ${ }^{19,20}$ 
Metode deteksi yang digunakan dalam penelitian ini adalah teknik immunositokimia dengan menggunakan antibodi DSSE10 produksi laboratorium Fakultas Kedokteran Universitas Gadjah Mada (UGM). Metode tersebut telah penulis publikasikan pada artikel sebelumnya dan terbukti sahih dalam mendeteksi keberadaan antigen virus DEN-3. Hasil positif ditunjukkan dengan adanya warna coklat pada granula dan sitoplasma pada hemosit sedangkan hasil negatif ditunjukkan dengan tidak adanya warna coklat atau terlihat warna biru kehijauan. ${ }^{20}$ Tulisan ini bertujuan untuk menganalisis pengaruh lama penyimpanan telur terhadap TIR virus DEN-3 pada nyamuk Ae. aegypti.

\section{METODE}

Jenis penelitian adalah penelitian laboratoris dengan rancangan penelitian eksperimental. Penelitian telah mendapatkan persetujuan etik No KE/FK/285/EC/2016 dari The Medical and Health Research Ethics Committee (MHREC) Faculty of Medicine Gadjah Mada University. Penelitian dilakukan di Laboratorium Parasitologi Fakultas Kedokteran Universitas Gadjah Mada pada bulan Januari-Juni 2017.

Nyamuk uji diperoleh dari koloni nyamuk Ae. aegypti Laboratorium Parasitologi Fakultas Kedokteran UGM, jumlah sampel sebanyak 200 ekor nyamuk betina. Teknik pengambilan sampel yang digunakan adalah simple random sampling yaitu pengambilan sampel secara acak dari suatu populasi tanpa memperhatikan strata yang ada dalam populasi. $^{21}$ Setiap individu nyamuk mempunyai kesempatan yang sama untuk terpilih menjadi sampel. Homogenitas koloni dipisahkan berdasarkan umur nyamuk (waktu ekskosi dari pupa menjadi nyamuk dewasa).

Sebanyak 200 nyamuk betina dewasa diambil dari koloni dengan cara mengambil nyamuk betina yang resting di semua sisi dinding kandang koloni dengan jeda waktu antar pengambilan nyamuk selama 10 detik. Untuk mengurangi bias agar nyamuk yang tertangkap bukan hanya nyamuk yang "kurang aktif" maka dilakukan jeda dalam pengambilan nyamuk untuk jumlah nyamuk berikutnya.

Cara pengujian dalam penelitian ini adalah menginfeksi nyamuk Ae. aegypti betina umur tujuh hari dengan suspensi DEN-3 (campuran virus DEN-3, darah manusia sehat, dan sukrosa $10 \%$ dengan perbandingan 1:1:1) secara per-oral melalui membrane feeding. Kandang nyamuk yang telah diinfeksi kemudian dipasang ovitrap dan diinkubasikan selama 7 hari untuk menjalani siklus gonotrofiknya dan diambil telurnya.

Telur kemudian disimpan pada suhu kamar $\left(25 \pm 3^{\circ} \mathrm{C}\right)$ dan kelembapan relatif $70 \pm 5 \%$ dengan variabel $0,1,2$ dan 3 bulan. Suhu dan kelembapan ruang rearing dijaga dengan menggunakan pendingin ruangan dan penggunaan handuk yang dibasahi pada kandang koloni nyamuk. Telur ditetaskan sesuai dengan variabel lama penyimpanan kemudian dilakukan rearing sampai menjadi nyamuk dewasa. Nyamuk dipisahkan ke beberapa kandang berdasarkan umur nyamuk (waktu eksklosi dari pupa menjadi nyamuk dewasa) sebanyak tiga kandang. Selanjutnya, tiap kandang diambil 30 ekor nyamuk betina dengan variabel umur 4,8 dan 16 hari. Nyamuk tersebut merupakan sampel untuk pembuatan preparat head squash dengan metode imunositokimia SBPC menggunakan kit Starr Trek Universal HRP Detection Biocare Medical Cat. No. 18007999499 dan dilakukan deteksi keberadaan antigen virus DEN-3. Deteksi antigen virus dengue menggunakan antibodi monoklonal DSSE 10 (spesifik virus dengue) produksi Laboratorium Fakultas Kedokteran UGM.

Deteksi keberadaan antigen virus DEN-3 menggunakan mikroskop binokuler dengan pembesaran 400x dan 1000x. Adanya antigen virus DEN-3 ditunjukkan dengan adanya warna coklat pada granula dan sitoplasma pada hemosit dari sediaan head squash. Hasil negatif ditunjukkan dengan tidak adanya warna coklat atau terlihat warna biru kehijauan. Transovarial infection rate diperoleh dengan menghitung jumlah sampel positif dibagi total sampel dikalikan $100 \%$. 
Data pengaruh lama penyimpanan terhadap derajat infeksi transovarial virus dengue metode imunositokimia SBPC dianalisis dengan menggunakan uji regresi linier.

\section{HASIL}

Hasil deteksi antigen virus dengue pada sediaan head squash dengan metode imunositokimia SBPC disajikan pada Tabel 1.

Tabel 1. Hasil Deteksi Antigen Virus Dengue pada Sediaan Head Squash Nyamuk Ae. aegypti dengan Metode Imunositokimia SBPC

\begin{tabular}{lcccc}
\hline \multirow{2}{*}{ Umur Nyamuk } & \multicolumn{4}{c}{ Transovarial Infection Rate (\%) } \\
\cline { 2 - 4 } & 0 bulan & 1 bulan & 2 bulan & 3 bulan \\
\hline 4 hari & 33,33 & 50,00 & 76,67 & 56,67 \\
8 hari & 13,33 & 56,67 & 66,67 & 56,67 \\
16 hari & 40,00 & 43,33 & 76,67 & 56,67 \\
\hline
\end{tabular}

Hasil pemeriksaan antigen virus DEN3 dengan metode imunositokimia SBPC pada sediaan head squash nyamuk dewasa Ae. aegypti menunjukkan hasil yang positif dengan TIR yang bervariasi. Transovarial Infection Rate terendah terlihat pada nyamuk dewasa umur 8 hari dari sampel telur dengan lama penyimpanan 0 bulan sebesar 13,33\%. Transovarial Infection Rate tertinggi terlihat pada nyamuk dewasa umur 4 dan 8 hari dari sampel telur nyamuk dengan lama penyimpanan 2 bulan, sebesar 76,67\%.

Pola kenaikan dan penurunan derajat infeksi transovarial virus DEN-3 pada nyamuk Ae. aegypti dapat terlihat pada Gambar 2.
Hasil uji statistik pengaruh lama penyimpanan telur terhadap TIR dengan menggunakan uji regresi linear menunjukkan hasil yang berbeda nyata $(\mathrm{p}=0,013)$ dengan nilai $\alpha=0,05$ dan nilai $\mathrm{R} 2=0,476$. Dengan hasil ini dapat disimpulkan bahwa lama penyimpanan telur berpengaruh terhadap TIR virus DEN-3 pada nyamuk Ae. aegypti. Variabel lama penyimpanan telur memiliki pengaruh kontribusi sebesar $47,6 \%$ terhadap TIR virus DEN-3 pada nyamuk Ae. aegypti.


Gambar 2. Grafik Pengaruh Lama Penyimpanan Telur terhadap TIR virus DEN-3 pada Nyamuk Ae. Aegypti 


\section{PEMBAHASAN}

Transmisi transovarial DENV 1-4 telah dibuktikan baik secara laboratorium maupun di alam. ${ }^{14,16,20,22-25}$ Transmisi transovarial virus dengue pada nyamuk $A e$. aegypti dianggap merupakan mekanisme yang sangat penting dalam pemeliharaan dan distribusi virus dengue di alam..$^{26,27}$

Hasil pemeriksaan antigen virus DEN3 dengan metode imunositokimia SBPC pada sediaan head squash nyamuk dewasa Ae. aegypti menunjukkan hasil yang positif sampai masa penyimpanan telur 3 bulan dengan derajat infeksi transovarial sebesar 56,67\% pada semua sampel nyamuk dewasa umur 4,8 , dan 16 hari. Hal ini mengindikasikan kemampuan virus dengue bertahan pada telur nyamuk selama masa inter-epidemic melalui kemampuan transmisi transovarial. Transmisi transovarial merupakan aspek yang sangat penting dalam menjaga virus dengue selama masa inter-epidemic di alam, ${ }^{14}$ saat kondisi lingkungan tidak memungkinkan untuk terjadinya transmisi horizontal. ${ }^{28}$ Umniyati menyatakan bahwa telur-telur yang diletakkan pada akhir musim hujan sebelumnya akan menetas pada awal musim hujan berikutnya, jika telur tersebut berasal dari induk infeksius, maka sebagian telur tersebut berpeluang untuk terinfeksi secara transovarial selama stadium telur yang berlangsung selama berbulanbulan. ${ }^{11}$ Telur yang menetas pada musim hujan berikutnya tersebut berpeluang besar menjadi larva yang infeksius dan selanjutnya menjadi nyamuk yang infeksius virus dengue walaupun belum pernah menggigit dan menghisap darah inang infeksius virus dengue.

Kondisi tersebut berpotensi sebagai faktor pendukung pemeliharaan endemisitas DBD dengan cara pemeliharaan keberadaan virus dengue di suatu wilayah. Nyamuk yang mendapatkan kesempatan untuk menghisap darah inang viraemia sebelum musim panas dan meletakkan telurnya pada lingkungan yang sesuai menyebabkan sebagian telur dapat bertahan hidup selama masa inter-epidemic dan memulai daur hidup virus antar nyamukmanusia-nyamuk akan berdampak pada kejadian DBD. Kemampuan nyamuk $A \boldsymbol{e}$. aegypti mempertahankan dan mentransmisikan virus dengue kepada generasi berikutnya secara transovarial dapat memberikan pola distribusi dan variasi musiman terjadinya insiden DBD pada daerah endemis dengue.

Berdasarkan lama penyimpanan telur terlihat adanya tren kenaikan derajat infeksi transovarial pada semua sampel sampai lama penyimpanan telur 2 bulan dan mengalami penurunan pada lama penyimpanan telur 3 bulan. Trend kenaikan tertinggi terjadi pada sampel umur 8 hari mulai dari $13,33 \%$ pada lama penyimpanan telur 0 bulan menjadi $66,67 \%$ pada lama penyimpanan telur 2 bulan kemudian menurun menjadi $56,67 \%$ pada lama penyimpanan telur 3 bulan. Trend kenaikan terendah terjadi pada sampel umur 16 hari mulai dari $40,00 \%$ pada lama penyimpanan telur 0 bulan menjadi $76,67 \%$ pada lama penyimpanan telur 2 bulan kemudian menurun menjadi $56,67 \%$ pada lama penyimpanan telur 3 bulan. Hasil penelitian ini sesuai dengan penelitian sebelumnya oleh Mourya et al. bahwa angka infeksi transovarial virus dengue semakin tinggi pada nyamuk yang menetas dari telur yang lebih lama tersimpan dalam kondisi suhu kamar. ${ }^{6}$ Hal ini terjadi karena sebelum menetas virus dalam embrio mempunyai peluang lebih lama untuk propagasi. Setelah berkembangan embrio sempurna, telur Ae. aegypti dapat bertahan pada keadaan kering dalam waktu yang lama (lebih dari satu tahun). Hal berbeda dilaporkan oleh Satoto yang menyatakan tidak adanya perbedaan yang bermakna antara lama penyimpanan telur ( 7 dan 14 hari) dengan angka infeksi transovarial. ${ }^{12}$ Pada penelitian ini TIR diperiksa dengan variabel lama penyimpanan $0,1,2,3$ bulan sedangkan pada penelitian Wasinpiyamongkol hanya pada telur yang disimpan 1 bulan, penelitian Mourya hanya pada telur yang disimpan 2 bulan dan Suardipa hanya pada lama penyimpanan 7 dan 14 hari. $^{6,12,13}$

Infection rate tertinggi diperoleh pada masa inkubasi 2 bulan baik pada sampel umur 4, 8, maupun 16 hari sebesar 76,67\%; 66,67\%; 
76,67\%. Hasil derajat infeksi transovarial paling tinggi dan dapat terdeteksi secara optimum pada sampel lama penyimpanan telur 2 bulan. Hal ini sesuai dengan hasil penelitian Mourya et al. dimana didapatkan angka infection rate yang sangat tinggi (50-63\%) yang didapatkan dari telur yang disimpan pada suhu kamar selama 1 atau 2 bulan. ${ }^{6}$ Joshi et al. melaporkan derajat infeksi virus DEN-3 yang sangat tinggi yang diperoleh dari nyamuk lapangan. Hal ini dimungkinkan karena telur yang diambil sebagai sampel merupakan telur yang sudah ada dan berdiam di lapangan dalam waktu yang lebih lama. ${ }^{29}$

Pada sampel lama penyimpanan telur 0 dan 1 bulan diperoleh nilai derajat infeksi transovarial yang lebih rendah kemungkinan terjadi karena pada sampel tersebut mengandung jumlah virus yang lebih sedikit sehingga nilai derajat infeksinya lebh rendah. Penurunan angka derajat infeksi transovarial pada sampel lama penyimpanan telur 3 bulan kemungkinan terjadi karena viabilitas virus dengue yang semakin menurun. Penelitian ini menyimpulkan bahwa kemungkinan virus dengue mungkin tidak mengalami periode laten pada masa telur (embrio) seperti mekanisme yang dipercaya untuk menjaga keberadaan virus pada periode inter-epidemic selama ini. Hasil penelitian ini menunjukkan bahwa virus dengue tetap berkembangbiak dalam embrio di dalam telur.

Peningkatan TIR dimungkinkan juga karena adanya kondisi lingkungan yang mendukung perkembangan nyamuk. Kondisi lingkungan yang optimum selama masa perlakuan dan pemeliharaan nyamuk dengan suhu kamar $\left(25 \pm 3^{\circ} \mathrm{C}\right)$ dengan kelembaban relatif $70 \pm 5 \%$ menunjang perkembangan nyamuk secara optimum. Nyamuk umumnya meletakkan telurnya pada suhu $20-30^{\circ} \mathrm{C}$ dan suhu optimum untuk pertumbuhan dan perkembangan nyamuk $25-27^{\circ} \mathrm{C} .^{30}$ Suhu merupakan faktor yang penting dalam perkembangan siklus kehidupan nyamuk. Nyamuk merupakan hewan berdarah dingin yang tergantung pada suhu lingkungan sekitar sehingga sangat tergantung pada perubahan suhu. ${ }^{31}$ Perubahan suhu dapat mempengaruhi efisiensi penyebaran dan transmisi virus, peningkatan suhu lingkungan sekitar dapat meningkatkan replikasi virus pada jaringan nyamuk. Kondisi lingkungan yang sesuai khususnya suhu dan kelembapan untuk perkembangan nyamuk akan mendukung perkembangan dan replikasi virus dengue mulai dari fase embrional dalam telur sampai stadium dewasa di dalam tubuh nyamuk.

\section{KESIMPULAN}

Lama penyimpanan telur berpengaruh terhadap TIR virus dengue 3 pada nyamuk $A e$. aegypti yang diinfeksi dengan virus dengue secara per-oral. Variabel lama penyimpanan telur memiliki pengaruh kontribusi sebesar 47,6\% terhadap TIR virus DEN-3 pada nyamuk Ae. aegypti. Angka TIR naik mulai dari penyimpanan telur 0-2 bulan dan menurun pada penyimpanan telur 3 bulan.

\section{SARAN}

Perlu penelitian dengan interval dan lama waktu perlakuan terhadap telur sesuai musim kemarau di Indonesia yang rata-rata berlangsung selama 6 bulan sehingga efek infeksi virus DEN-3 terhadap derajat infeksi transovarial selama periode inter-epidemic bisa tergambarkan secara menyeluruh.

\section{UCAPAN TERIMA KASIH}

Penulis mengucapkan terima kasih kepada Badan PPSDM selaku penyandang dana penelitian ini, kepada Ibu Siti Rahmah Umniyati dan bapak Tri Baskoro Tunggul Satoto atas bimbingannya, seluruh tenaga laboratorium parasitologi, mikrobiologi dan molekuler Fakultas Kedokteran UGM atas semua bantuan dan kerjasamanya.

\section{DAFTAR PUSTAKA}

1. Kementerian Kesehatan RI. Profil kesehatan RI 2015. Jakarta: Kementerian Kesehatan RI; 2016.

2. Henchal EA, Putnak JR. The dengue viruses. Clin Microbiol Rev. 1990;3(4):376-96. 
3. Andrade EHP, Figueiredo LB, Vilela APP, Rosa JCC, Oliveira JG, Zibaoui HM, et al. Spatial-temporal co-circulation of dengue virus 1, 2, 3, and 4 associated with coinfection cases in a hyperendemic area of Brazil: A 4-week survey. Am J Trop Med Hyg. 2016;94(5):1080-4.

4. Fadilla Z, Hadi U, Setiyaningsih S. Bioekologi vektor demam berdarah dengue (DBD) serta deteksi virus dengue pada Aedes aegypti (Linnaeus) dan Ae. albopictus (Skuse) (Diptera: Culicidae) di kelurahan endemik DBD Bantarjati, Kota Bogor. J Entomol Indones. 2016;12(1):31-8.

5. Wilder-Smith A, Ooi EE, Horstick O, Wills B. Dengue. Lancet. 2019;393(10169):350-63.

6. Mourya DT, Gokhale, Basu A, Barde PV; Sapkal GN, Padbidri VS. Horizontal and vertical transmission of dengue virus type 2 in highly and lowly susceptible strains of Aedes aegypti mosquitoes. Acta Virol. 2001;45(2):67-71.

7. Lequime S, Paul RE, Lambrechts L. Determinants of arbovirus vertical transmission in mosquitoes. PLoS Pathog. 2016;12(5):1-14.

8. Janah M, Pawenang E. Karakteristik sumur gali dan keberadaan jentik Aedes aegypti. HIGEIA (Journal of Public Health Research and Development). 2017;1(1):8-14.

9. Embong N, Sudarmaja I. Pengaruh suhu terhadap angka penetasan telur Aedes aegypti. E-Jurnal Med Udayana. 2016;5(12):1-8.

10. Alfiah RS, Alfiah S. Pengaruh suhu penyimpanan terhadap presentase tetas telur. Vektora. 2014;6(1):9-12.

11. Umniyati SR. Tehnik imunositokimia dengan antibodi monoklonal DSSC7 untuk kajian patogenesis infeksi dan penularan transovarial virus dengue serta surveilansi virologis vektor dengue [Disertasi]. Yogyakarta: Universitas Gadjah Mada; 2009.

12. Satoto TBT, Umniyati S, Suardipa A, Sintorini M. Effects of temperature, relative humidity, and DEN-2 virus transovarial infection on viability of Aedes aegypti. Kesmas Natl Public Heal J. 2013;7(7):331-6.

13. Wasinpiyamongkol L, Thongrungkiat $\mathrm{S}$, Jirakanjanakit N, Apiwathnasorn C. Susceptibility and transovarial transmission of dengue virus in Aedes aegypti: a preliminary study of morphological variations. Southeast Asian J Trop Med Public Health. 2003;34 Suppl 2(Suppl 2):131-5.

14. da Cruz LC de TA, Serra OP, Leal-Santos FA, Ribeiro ALM, Slhessarenko RD, Santos MA. Natural transovarial transmission of dengue virus 4 in Aedes aegypti from Cuiabá, State of Mato Grosso, Brazil. Rev Soc Bras Med Trop. 2015;48(1):18-25.

15. Satoto TBT, Umniyati SR, Astuti FD, Wijayanti N, Gavotte L, Devaux C, et al. Assessment of vertical dengue virus transmission in Aedes aegypti and serotype prevalence in Bantul, Indonesia. Asian Pacific J Trop Dis. 2014;4(S2):S563-8.

16. Da Costa CF, Dos Passos RA, Lima JBP, Roque RA, De Souza Sampaio V, Campolina TB, et al. Transovarial transmission of DENV in Aedes aegypti in the Amazon basin: a local model of xenomonitoring. Parasites and Vectors. Parasites \& Vectors; 2017;10(1):1-9.

17. Widiastuti D, Kesuma AP, Pramestuti N. Entomological index and transovarial transmission contribute to dengue haemorrhagic fever outbreaks in Banjarnegara Regency. Spirakel. 2016;8(1):30-7.

18. Yang HM. The transovarial transmission in the dynamics of dengue infection: Epidemiological implications and thresholds. Math Biosci. 2017;286:1-15.

19. Lidiasani M, Sorisi A, Pijoh. V. Deteksi transmisi transovarial virus dengue pada Aedes aegypti dengan teknik imunositokimia di Kota Manado. J e-Biomedik. 2016;4(1):116-21.

20. Wahono T, Umniyati SR. Deteksi transmisi transovarial virus DEN-3 pada nyamuk Aedes aegypti dengan teknik imunositokimia menggunakan antibodi DSSE10. Spirakel. 2018;10(1):21-30.

21. Sugiyono. Statistika untuk penelitian. Bandung: Alfabeta; 2010.

22. Setya AK. Deteksi transmisi transovarial virus DEN-3 pada semua stadium Aedes aegypti secara imunositokimia dengan konfirmasi RTPCR [Thesis]. Surakarta: Universitas Negeri Surakarta; 2015.

23. Saraswati NM. Detection Of transovarial dengue virus transmission in Aedes aegypti mosquitoes From Kampung Inggris, Pare, Kediri, East Java [Skripsi]. Yogyakarta: 
Fakultas Kedokteran Universitas Gadjah Mada.; 2017.

24. Edillo FE, Sarcos JR, Sayson SL. Natural vertical transmission of dengue viruses in Aedes aegypti in selected sites in Cebu City, Philippines. J Vector Ecol. 2015;40(2):282-91.

25. Wanti W, Sila O, Irfan I, Sinaga E. Transovarial transmission and dengue virus serotypes in Aedes aegypti in Kupang. J Kesehat Masy. 2016;12(1):131-8.

26. Ferreira-De-Lima VH, Lima-Camara TN. Natural vertical transmission of dengue virus in Aedes aegypti and Aedes albopictus: A systematic review. Parasites and Vectors. Parasites \& Vectors; 2018;11(1):1-8.

27. Grunnill M, Boots M. How important is vertical transmission of dengue viruses by mosquitoes (Diptera: Culicidae)?. J Med Entomol. 2016;53(1):1-19.
28. Gutiérrez-Bugallo G, Rodriguez-Roche R, Díaz G, Vázquez AA, Alvarez M, Rodríguez $\mathrm{M}$, et al. First record of natural vertical transmission of dengue virus in Aedes aegypti from Cuba. Acta Trop. 2017;174:146-8.

29. Joshi V, Mourya DT, Sharma RC. Persistence of dengue-3 virus through transovarial transmission passage in successive generations of Aedes aegypti mosquitoes. Am J Trop Med Hyg. 2002;67(2 SUPPL.):158-61.

30. Rohani A, Zamree I, Lee HL, Mustafakamal I, Norjaiza MJ, Kamilan D. Detection of transovarial dengue virus from field-caught Aedes aegypti and Ae. albopictus larvae using C6/36 cell culture and reverse transcriptasepolymerase chain reaction (RT-PCR) techniques. Dengue Bull. 2007;31:47-57.

31. Samuel GH, Adelman ZN, Myles KM. Temperature-dependent effects on the replication and transmission of arthropodborne viruses in their insect hosts. Curr Opin Insect Sci. 2016;16:108-13. 